\title{
Comparative Analysis of Educational Programs for Training Social Pedagogues on the Example of Universities in Kazakhstan, Lithuania and Germany
}

\author{
(D)Akmaral Magauova ${ }^{1}$ Doctor of Ped. Sc.; (Dhamilya Makhambetova ${ }^{2}$ MSc in Social Sciences \\ Svetlana Lukashova ${ }^{3}$ MSc in Social Sciences \\ Al-Farabi Kazakh National University, Republic of Kazakhstan ${ }^{1,2}$; Suleyman Demirel University ${ }^{3}$ \\ Republic of Kazakhstan \\ magauova@mail.ru1; mzhamilya@mail.ru²; svetlana.lukashova@sdu.edu.kz ${ }^{3}$
}

\begin{abstract}
In the context of integration of national education systems into a single global educational space, the competency-based paradigm of education serves as the main for training competitive strategy specialists. The transition to competency-based educational standards of higher education involves the formation of students' professional competences for successful professional activity. The aim of the research is to study and analyse the experience of development of professional competences in the training of social pedagogues in Kazakhstan, Lithuania, and Germany. In this paper, the study and comparative analysis of the experience of forming professional competences in the training of social pedagogues in Kazakhstan, Lithuania and Germany are carried out. The research showed that during the period of study at the University in the specialty "Social pedagogy and self-cognition", it is necessary to introduce a competency-based approach aimed at the formation of professional competences for working in an inclusive education. As a result of the research, the nature and trends of training social pedagogues in three countries are identified, then general and special competences of social pedagogues are analysed; finally, the professional competences adopted by the world community are highlighted.
\end{abstract}

Keywords: comparative, descriptive analysis; inclusive education; professional competence; social pedagogy.

\section{Introduction}

In pedagogical science and practice, the problems of formation of students' competences are updated, which is reflected in the system of new requirements of the competence approach to the training of specialists, which are laid down in the State Mandatory Standard of Education (SMSE) of higher professional education of the Republic of Kazakhstan in accordance with the competency-based paradigm of education. The competency-based paradigm of education contributes to the formation of a competent specialist, defining his personal and professional development, knowledge, moral values and role in society, thereby meeting the requirements of modern society for future specialists (Spencer, Spencer, 1993).

Reviewing the recent literature, the problem of forming professional competencies of future social pedagogues still remains relevant. Social pedagogues are graduate professionals, who have usually undertaken vocational degrees of three to four years, or a longer master's degree, both supplemented by continuing professional education. Lower-level courses can lead to employment but not to qualification; in many countries, unqualified social pedagogues are in the minority in, for example, children's residential care (Moss, Petrie, 2019). In social pedagogy, theory and practice, thought and action, come together (Hämäläinen, 2003). In practice, social pedagogy is considered a dynamic, humanistic approach to education that takes account of, but goes beyond, subject learning (Kyriacou et al., 2009).

It is a fact that the specialty of "social pedagogue" has a great importance in modern society. It is necessary to pay attention to the training of highly qualified social pedagogues. Many articles are devoted to this issue. The degree of future pedagogues' professional orientation gradually increases from first to third year and decreases by fourth year. There is a positive correlation between a high level of orientation toward the pedagogical profession and the following personal characteristics of students: a sense of their own self-efficacy; belief in the world's benevolence; realization of responsibility for their own actions in life and their personally significant choices; other-oriented perfectionism; tolerance of uncertainty; positive perception of the past and hedonistic and fatalistic perception of the present; global self-attitude (self-respect, self-affection, and self-interest); high degree of self-organization (goal-orientedness, perseverance, and orientation toward the present) (Shashkov et al., 2020). 
In Germany social pedagogy has emerged as an academic science in which theory and practice have developed in a dynamic and reflexive way. Due to this relationship, 'in which theoretical discourses and models for practice develop in mutual reference, without one simply being derived from the other' social pedagogy can be described as an action-orientated social science, concerned with practical or social issues while referring to theoretic knowledge in a given discipline (Cameron, Moss, 2011).

The aims and content of academic study programs in social pedagogy are connected with the understandings of social pedagogy's theoretical foundations, the most important schools of thought included, as well as with the vision of social pedagogical practice and the nature of professional expertise (Hämäläinen, 2019). L. Smekalova and K. Nemejc emphasized that social and civic competence is well developed by teaching these subjects - Social Pedagogy, Consultancy, Social Psychology, Pedagogy of Leisure Time and Basics of Special Pedagogy (Smekalova, Nemejc, 2016, 109). The research outcomes of Z. Anspoka and D. Kazaka (2019) enable us to think that one of the problems for more successful work, when implementing the set requirements for modern teaching and learning process, is insufficient communication among the different subject teachers. The study shows that teachers perceive their colleagues not as cooperation partners but rather than competitors. According to the education reform's purpose to improve education outcomes, $82 \%$ of the surveyed respondents admit that not only the subject teachers' mutual collaboration, but also the teachers and support staff's (librarians, psychologists, social pedagogues, speech therapists, career consultants) cooperation has to be improved (Anspoka, Kazaka, 2019, 25).

T. Delcheva (2019) presented a study, which is a part of a broader study that aimed to analyse, and - if required - to modernize or optimize the organization of the practical training of Social Pedagogy students to ensure its coherence with the dynamic conditions for professional realization. The researcher's article focused on the final stage of the practical training of the students - the pre-graduate internship. The accent is the final product - a description of the pre-graduate internship; which is presented and defended at the state final certification examination.

Due to globalization, there has been a change in the social environment, economic security of family and social security of pupils. The result is the change of behaviour and socialization in school, leading to undesirable practices in primary schools, such as bullying, truancy, drugs, rebellion, violence, emotional abuse and so forth. Social pedagogues are experts in schools that can help in these areas and can help to harmonize the school environment (Durana, Chlebikova, 2017).

The aim of the research is to study and analyse the experience of the development of professional competences in the training of social pedagogues in Kazakhstan, Lithuania and Germany; to determine patterns and trends, common and particular competences of preparation of social pedagogues in the three countries; to designate the need for the inclusion of professional competences for work in inclusive education in the educational program, and State Mandatory Standard of Education of Republic of Kazakhstan for training of social pedagogues, as well as about the need to use the opportunities of major subjects in the formation of professional competences of social pedagogues on the example of universities in the Republic of Lithuania and Germany.

\section{Methodology}

In this paper, a comparative, descriptive analysis of the selected educational programs for training social pedagogues of 3 higher educational establishments: Al-Farabi Kazakh National University (Almaty, Republic of Kazakhstan), College of Utena (Utena, Lithuania) and Leuphana College at Leuphana University (Luneburg, Germany) was carried out in the 2019-2020 academic year; the structure and content, the possibilities of curricula of the specialty "Social pedagogy" in the formation of professional competences were described. Comparative and descriptive analyses were used (Loeb et al., 2017), research data collected during the analysis of literature review and normative data were presented: the State mandatory standard of education of the Republic of Kazakhstan; data from the website for the training of social pedagogues at Al-Farabi Kazakh National University; the curriculum of the Educational program "6B018-Social pedagogy and self-cognition" Al-Farabi KazNU (Obrazovatel'naya programma Podgotovka..., 2020); Vocational Education and Training Standard for a Social Pedagogue (Vocational Education and..., 2008); Educational program for training social pedagogues in Utena (Social pedagogues..., 2019). 


\section{Results and discussion}

General information about the educational institutions that were selected for the comparative analysis of the training of social pedagogues is described in Table 1.

Table 1

General information (prepared by the authors)

\begin{tabular}{|c|c|c|c|c|}
\hline $\mathbf{N}$ & information country & Republic of Kazakhstan & Lithuania & Germany \\
\hline 1. & $\begin{array}{l}\text { Name of the } \\
\text { educational } \\
\text { institution }\end{array}$ & $\begin{array}{l}\text { Al-Farabi Kazakh National } \\
\text { University (Almaty, Republic } \\
\text { of Kazakhstan) }\end{array}$ & $\begin{array}{l}\text { Utenos kolegija, } \\
\text { University of Applied } \\
\text { Sciences (Lithuania). }\end{array}$ & $\begin{array}{l}\text { Leuphana College at } \\
\text { Leuphana University } \\
\text { (Luneburg, Germany) }\end{array}$ \\
\hline 2. & $\begin{array}{l}\text { Type of educational } \\
\text { institution }\end{array}$ & university & college (at university) & $\begin{array}{l}\text { college (at } \\
\text { university) }\end{array}$ \\
\hline & $\begin{array}{l}\text { Total number of } \\
\text { students }\end{array}$ & $\begin{array}{l}\text { More than } 25,000 \text { students and } \\
\text { undergraduates }\end{array}$ & $2,000-2,999$ students & 9888 students \\
\hline 3. & Level of training & \multicolumn{3}{|l|}{ bachelor } \\
\hline 4. & Graduate degree & $\begin{array}{l}\text { Bachelor of education } \\
\text { according to the educational } \\
\text { program "6B018-Social } \\
\text { pedagogy and self-cognition" }\end{array}$ & Professional bachelor & $\begin{array}{l}\text { Bachelor of Arts } \\
\text { (B.A.) }\end{array}$ \\
\hline 5. & Language of study & Kazakh, Russian & $\begin{array}{c}\text { Lithuanian, English, } \\
\text { Russian }\end{array}$ & German, English \\
\hline 6. & $\begin{array}{l}\text { Duration of the } \\
\text { training program }\end{array}$ & 4 years $(8$ terms $)$ & $\begin{array}{c}\text { Full-time education-3 } \\
\text { years, part-time-4 years }\end{array}$ & $\begin{array}{c}\text { Standard training is } \\
3 \text { years }\end{array}$ \\
\hline 7. & Number of credits & 240 credits & 180 credits & 180 credits \\
\hline
\end{tabular}

\section{Experience in training social pedagogues in the Republic of Lithuania.}

After analysing the educational program in the specialty "Social pedagogy" at the Utena University of Applied Sciences Educational program for training social pedagogues in Utena (Social pedagogues..., 2019), it should be noted that this program involves the formation of future social pedagogues of the following competences: 1) Communicate in the correct Lithuanian language in all conditions of selfeducation. 2) Use one foreign language at least B2 in accordance with the Common European system of languages (CEFR). 3) Collect, process, analyse, summarize and interpret research results. 4) Determine the problem of education and training; formulate the aim, objectives and hypotheses of the study. 5) Create a safe, tolerant, open, encouraging group learning and collaborative environment. 6) Communicate, collaborate and motivate students, parents (foster parents), colleagues, and representatives of institutions that provide social and educational services and strive for common goals. 7) Evaluate the development of the student, recognizing the individuality of the individual. 8) Organize preventive work. 9) Organize and evaluate work with students and their groups.10) Assessment and organization of work with students' families.11) Coordination of interagency interaction and cooperation. 12) Take responsibility for the results of their own work, assess their relevance and consequences for human values. 13) Think about own pedagogical, andragogical, or other educational activities. 14) Use of various learning tools, digital technologies and software / hardware, increasing the diversity of learning activities. 15) Improving the professional and personal competences of a social pedagogue.

The above-mentioned competences correspond to the competences of the Vocational Education and Training Standard for a Social Pedagogue (Vocational Education and..., 2008): 1. Assessment of the student's needs in the environment and prevention; 2. Development and implementation of preventive and social projects and programs; 3 . Analysis of the effectiveness of preventive work; 4 . Assessment of the student's needs and social problems; 5 . Solving problems related to the integration of socio-cultural differences; 6. Organization of activities of children at risk; 7.Assessment of the effectiveness of sociopedagogical impact on the pupil; 8. Assessment of the child's family social environment; 9. Organization of social support for students' families; 10 . Promotion of a positive lifestyle in families; 11 . Coordination of social and pedagogical support in cooperation and communication with institutions; 12. 
Communication and cooperation with students and other participants in the educational process; 13. Conducting applied research; 14. Assessment of personal professional activity.

The analysis of normative documents of Lithuania has shown that the training of future social pedagogues and the development of their competences have a profile orientation and provide for the training of social pedagogues to work in an inclusive education environment. This is facilitated by the study of the following subjects: "Education about child health", "Work of a social pedagogue", "Protection of children's rights".

\section{Bachelor's degree in social pedagogy in College of Utena (Utena, Lithuania).}

Training in College of Utena (Utena, Lithuania) is conducted in 3 languages: Lithuanian, English, Russian. Full-time education-3 years, part-time-4 years. The aim of the program: to train a specialist who can organize preventive work, work with groups of students and their families, teach communication and cooperation skills, and contribute to the personal and professional development of a social pedagogue (Social pedagogues..., 2019).

In this programme 30 credits per semester are provided, no more than 7 modules per semester (Vocational Education and..., 2008). It should be noted that in College of Utena (Utena, Lithuania) the training of major subjects begins in the first year. Training is conducted in modules: "Human and environmental knowledge"; "Children's Education"; "Child and family"; "Factors of risk socialization", and others.

\section{Structure of training of social pedagogues at the Leuphana college at Leuphana University (Luneburg, Germany)}

At Leuphana College in Leuphana University (Luneburg, Germany), standard training is 3 years. College students combine social pedagogy with other subjects of their choice: German, English, Protestant studies, Mathematics, Politics, or Physical education. The language of the curriculum is German. Along with studying social pedagogy and the chosen subject, the program includes professionalization. The article examines the institutional and broader conceptual framework of vocational education in Germany, examines the theory of development, training and socialization, as well as tools for measuring and evaluating performance. It is necessary to note the role of the subject "Introduction to the discipline: theory and problems of social pedagogy", studied in the 1st year of study. The Bachelor of social pedagogy at Leuphana College is an extensive degree in social science.

Along with the theories of social pedagogy, as well as legal, organizational and financial aspects of social pedagogy, empirical methods of social research are deeply studied (disciplines: "Legislation, organization and financing of social pedagogy", "Applied methods and procedures of social pedagogy", "International perspectives of social pedagogy"). The program links academic interaction with research in social pedagogy with fundamental aspects of teaching and psychology. Subject-based academic and didactic skills are developed that lay the foundation for both research and teaching careers in professional or higher education. The bachelor of social pedagogy also opens up a number of other possible professions. For example, a student can continue his master's degree in educational science at another university or start working in child and youth welfare services that qualify as social pedagogy (Bachelor..., 2019).

\section{Structure of the training course for social pedagogues in Al-Farabi Kazakh National University.}

The practice of training social pedagogues in Kazakhstan was started in 2010. Normative documents, educational programs and curricula were developed to provide professional training of future specialists for social and pedagogical work. They reflected the international experience of training pedagogues and also took into account the features of the Kazakh system of higher professional education (Gosudarstvennyi obshyeobyazat'elnyi standart..., 2010).

In Al-Farabi Kazakh National University training in the specialty "Social pedagogy and self-cognition" is carried out at the Department of Pedagogy and educational Management of the Faculty of Philosophy and Political Science. Duration of training in bachelor degree 4 years, master degree -2 years. Training languages -Kazakh, Russian. The goal is to train highly qualified specialists perfectly with professional competence in the field of social pedagogics and self-cognition, prepare teachers of "Self-cognition" for schools that focus on spiritual and moral development of students, followed by universal values in life, developed deep and positive thinking, and readiness to implement in practice, the role of meta-subject 
"Self-cognition". When preparing bachelors, first of all, the main efforts of lecturers should be directed to the formation of professional competences that are developed in the study of a particular discipline. Future social pedagogues are expected to develop the following professional competences: special, communicative, informational, intellectual, social, personal, and profile. Graduates of the specialty "Social pedagogy and self-cognition" can work in the educational system as a social pedagogue; as a specialist in the protection of children's rights and other social support agencies for the unemployed and low-income; as an animator in child development centres and other companies. Graduates are awarded the qualification "Teacher of self-cognition, social pedagogue at school" (Bakalavriat..., 2019). For analysis, we selected the following subjects of the educational program "6B018-Social pedagogy and self-cognition" (Obrazovatel'naya programma Podgotovka..., 2020):

- "Social pedagogy";

- "Inclusive education";

- "Information and communication technologies".

According to the Curriculum of the educational program "6B018-Social pedagogy and self-cognition" from 2019, the subject "Social pedagogy" is considered as a major subject, it belongs to the mandatory component; pre-requisite - "Pedagogy", post-requisite - "Technologies of social and pedagogical work" (Obrazovatel'naya programma Podgotovka..., 2020) (Table 2).

Table 2

Information according to the curriculum of the educational program "Social pedagogy and selfcognition" (Obrazovatel'naya programma Podgotovka..., 2020) (prepared by the authors)

\begin{tabular}{|c|c|c|c|c|c|c|}
\hline \multicolumn{6}{|c|}{ Data of the subjects: "Social pedagogy", “Inclusive education" and "Information Communication } \\
Technology"
\end{tabular}

During studying the course "Social pedagogy" it is assumed to form competences that are indicated in the educational program as abilities (Table 3).

Table 3

Compliance of the required competences as a result of studying the discipline "Social pedagogy" with the competences according to State Mandatory Standard of Education of Republic of Kazakhstan (prepared by the authors)

\begin{tabular}{|c|c|c|c|}
\hline $\mathbf{N}$ & $\begin{array}{l}\text { Competences (abilities) formed } \\
\text { during the study of the subject }\end{array}$ & Requirements & $\begin{array}{l}\text { Competences as a result of studying } \\
\text { the subject according to State } \\
\text { Mandatory Standard of Education of } \\
\text { Republic of Kazakhstan }\end{array}$ \\
\hline 1. & $\begin{array}{l}\text { describe the subject of social pedagogy, } \\
\text { its components, phenomena and } \\
\text { patterns of social behaviour of } \\
\text { individuals and various groups }\end{array}$ & \multirow{5}{*}{$\begin{array}{l}\text { Professional } \\
\text { competency } \\
\text { includes special; } \\
\text { communication, } \\
\text { informational; } \\
\text { intellectual; } \\
\text { social: personal; } \\
\text { profile } \\
\text { competencies }\end{array}$} & intellectual competency \\
\hline 2. & $\begin{array}{l}\text { social interaction with the subjects of } \\
\text { the educational process }\end{array}$ & & $\begin{array}{l}\text { special, communicative, intellectual, } \\
\text { social, personal, profile competencies }\end{array}$ \\
\hline 3. & $\begin{array}{l}\text { determine the type of social influence } \\
\text { based on the described situation; - } \\
\text { Express the point of view on the tasks to } \\
\text { be solved }\end{array}$ & & $\begin{array}{l}\text { special; intellectual, personal, profile } \\
\text { competencies }\end{array}$ \\
\hline 4. & $\begin{array}{l}\text { develop positive communication skills; } \\
\text { conflict resolution skills, group work } \\
\text { organization }\end{array}$ & & $\begin{array}{l}\text { communicative, intellectual, social } \\
\text { competencies }\end{array}$ \\
\hline 5. & determine the type of social influence & & $\begin{array}{l}\text { special, communicative, informational, } \\
\text { intellectual, social, personal and profile } \\
\text { competencies }\end{array}$ \\
\hline
\end{tabular}


The analysis showed that the results of training of the discipline "Social pedagogy" do not fully reflect the professional competences. Both in the State Mandatory Standard of education and in the educational program are not provided the training of social pedagogues to work with people with special needs, disabilities, or to work in an inclusive education environment.

The discipline "Inclusive education" contributes to the formation of social pedagogue's competence to work in an inclusive education environment. According to the Curriculum of the educational program "6B018-Social pedagogy and self-cognition", the discipline "Inclusive education" belongs to the University component, there are no prerequisites, post - requirements - "Social pedagogy" (Table 3).

The term "inclusive education" has gained grounds internationally since the United Nations Salamanca Statement (UNESCO, 1994), signed by 192 member countries, which argued for schools with an inclusive orientation as being "the most effective means of combating discriminatory attitudes, creating welcoming communities, building an inclusive society and achieving education for all'. Inclusive education has grown to be much more than the mere acceptance of learners with disabilities into mainstream schools. It is accepted that there may be other barriers, such as age, gender, ethnicity, language, class or HIV status, that impact on learners' access to education. This broader understanding of inclusive education has a significant impact on the transformation of entire educational systems (Dreyer, 2017).

During studying the course "Inclusive education", it is assumed to form competences that are indicated in the educational program as abilities in Table 4.

The social pedagogue works in the conditions of informatization and computerization, so it is important to form his information competencies: skills to work with ICT, technological skills associated with the use of technology; computer skills and information management abilities. This is facilitated by studying the subjects of the "Instrumental module": "Information and communication technologies". According to UNESCO, "ICT is a scientific, technological, and engineering discipline and management technique used in the processing of information, its application and its connection with social, economic, and cultural issues" (Ratheeswari, 2018). The introduction and use of ICT in higher education has become a key issue in the development of the education system and they are commonly seen as the solution to the increasing demands on education systems. The integration of ICT into educational systems varies from the simple use of technology to assist instruction (e.g., Power Point presentations) to the delivery of whole courses or programs using ICT (e.g., Massive Open Online Courses (MOOC)) (Gasaymeh, 2018).

According to the Curriculum of the educational program "6B018-Social pedagogy and self-cognition", the discipline "Information and communication technologies" is a discipline of the "Instrumental module", general education discipline, a mandatory component, the subject is studied in English (Table 2).

In accordance with the requirements of State Mandatory Standard of Education of Republic of Kazakhstan specialty is the effectiveness of the social work pedagogue depends on the integration of theory and practice, as practice is the deepening and development of theoretical knowledge, and the establishment of their connection with practical activities. The most important condition for the success of the training of a social pedagogue is an organization of different types of practices: professional (learning) practice; vocational teacher training; professional (socio-pedagogical) practice; professional (learning) practice; professional (pre-diploma) practice.

So, comparing the educational programs of preparation of social pedagogues in 3 higher educational institutions of Kazakhstan, Lithuania, Germany indicates that in higher educational establishments of Lithuania and Germany training of students majoring begins with the 1st course, when Kazakhstan strengthened the study of major subjects starts from the 3rd semester.

In our research, we focus on the document "Professional competences of social pedagogues. Conceptual framework. International Association of Social Pedagogues", adopted by the European Bureau of the International Association of Social Pedagogues. This is the first document that established a set of criteria for the required level of competence required for the practice of social pedagogy (The professional competences ..., 2008). 
Compliance of the required competences as a result of studying the discipline "Inclusive education" with the competences according to State Mandatory Standard of Education of Republic of Kazakhstan 6.08.079-2010 (prepared by the authors)

\begin{tabular}{|c|c|c|c|}
\hline $\mathbf{N}$ & $\begin{array}{l}\text { Competences formed during the study of the } \\
\text { discipline }\end{array}$ & Requirements & $\begin{array}{l}\text { Competences as a result of } \\
\text { studying the discipline } \\
\text { according to State Mandatory } \\
\text { Standard of Education of } \\
\text { Republic of Kazakhstan }\end{array}$ \\
\hline 1. & $\begin{array}{l}\text { list general, specific patterns and individual features of } \\
\text { mental and psychophysiological development of } \\
\text { children/people; }\end{array}$ & \multirow{8}{*}{$\begin{array}{l}\text { Professional } \\
\text { competency } \\
\text { includes } \\
\text { special; } \\
\text { commu- } \\
\text { nication, } \\
\text { informational; } \\
\text { intellectual; } \\
\text { social: } \\
\text { personal; } \\
\text { profile } \\
\text { competencies }\end{array}$} & $\begin{array}{l}\text { special, intellectual, profile } \\
\text { competencies }\end{array}$ \\
\hline 2. & $\begin{array}{l}\text { describe models of inclusive education, the regulatory } \\
\text { and legal framework for teaching and raising children } \\
\text { with disabilities, Special Educational Needs, children of } \\
\text { the "risk" group }\end{array}$ & & $\begin{array}{l}\text { special, informational, } \\
\text { intellectual, personal } \\
\text { competencies }\end{array}$ \\
\hline 3. & $\begin{array}{l}\text { collect and primary process information about the history } \\
\text { of development and disease of children with different } \\
\text { types of disabilities }\end{array}$ & & $\begin{array}{l}\text { special, communicative, } \\
\text { informational, intellectual, } \\
\text { social, profile competencies }\end{array}$ \\
\hline 4. & $\begin{array}{l}\text { organize joint and individual activities of children with } \\
\text { different types of impaired development }\end{array}$ & & $\begin{array}{l}\text { special, communicative, } \\
\text { informational, intellectual, } \\
\text { social, profile competencies }\end{array}$ \\
\hline 5. & $\begin{array}{l}\text { apply strategies and methods of inclusive education, } \\
\text { organize child support for subjects of educational } \\
\text { integration }\end{array}$ & & $\begin{array}{l}\text { special, communicative, infor- } \\
\text { mational, intellectual, social, } \\
\text { personal, profile competencies }\end{array}$ \\
\hline 6. & $\begin{array}{l}\text { control the stability of his emotional state in interaction } \\
\text { with children who have SEN and their parents }\end{array}$ & & $\begin{array}{l}\text { intellectual, social } \\
\text { competencies }\end{array}$ \\
\hline 7. & $\begin{array}{l}\text { effectively interact with pedagogues of correctional } \\
\text { educational institutions and other specialists }\end{array}$ & & $\begin{array}{l}\text { special, communicative, social, } \\
\text { personal, profile competencies }\end{array}$ \\
\hline 8. & $\begin{array}{l}\text { analyse and evaluate the educational process for } \\
\text { children with SEN }\end{array}$ & & intellectual competencies \\
\hline
\end{tabular}

It should be noted that the competences formulated in the SMSE do not provide for the formation of future social pedagogues' professional competences to work with individuals with disabilities and SEN.

Professional competences include the following components (The professional competences ..., 2008) (Table 5).

Table 5

Professional competences according to International Association of Social Pedagogues

\begin{tabular}{|c|c|c|}
\hline $\mathbf{N}$ & Professional competences & Components \\
\hline 1. & $\begin{array}{l}\text { Personal competences and } \\
\text { competences of interactions }\end{array}$ & $\begin{array}{l}\text { dedication, motivation, attitudes, feelings, personal and } \\
\text { professional communication }\end{array}$ \\
\hline 2. & $\begin{array}{l}\text { Social and communicative } \\
\text { competences }\end{array}$ & $\begin{array}{l}\text { cooperation, constructive conflict resolution, communicative } \\
\text { competences at theoretical, practical, and methodological levels }\end{array}$ \\
\hline 3. & Organizational competences & $\begin{array}{l}\text { organization, management and development of social and } \\
\text { pedagogical institutions }\end{array}$ \\
\hline 4. & System competences & system competences cover the entire range of competences \\
\hline 5. & $\begin{array}{l}\text { Development and training } \\
\text { competencies }\end{array}$ & $\begin{array}{l}\text { continuous further education, assessment of his work } \\
\text { independently and together with others, the analysis of his work }\end{array}$ \\
\hline 6. & $\begin{array}{l}\text { Competences based on professional } \\
\text { experience }\end{array}$ & work experience \\
\hline
\end{tabular}




\begin{tabular}{|l|l|l|}
\hline $\mathbf{N}$ & \multicolumn{1}{|c|}{ Professional competences } & \multicolumn{1}{c|}{ Components } \\
\hline 7. & Methodological competences & $\begin{array}{l}\text { socio-pedagogical expertise and professionalism, theoretical and } \\
\text { practical knowledge, methods and tools }\end{array}$ \\
\hline 8. & $\begin{array}{l}\text { Behavioural competences in the } \\
\text { profession }\end{array}$ & $\begin{array}{l}\text { mastering the ethics and morals of the profession and influencing } \\
\text { their development }\end{array}$ \\
\hline 9. & Culturological competence & $\begin{array}{l}\text { knowledge, understanding and openness to different cultures and } \\
\text { cultural values }\end{array}$ \\
\hline 10. & Creative competences & $\begin{array}{l}\text { possession of forms of self-expression, creative skills. expanding } \\
\text { creative horizons in the social and cultural environment }\end{array}$ \\
\hline
\end{tabular}

\section{Conclusions}

Thus, as a result of a comparative analysis of the experience of forming professional competences in the training of social pedagogues in the countries we studied (Germany, Lithuania, Kazakhstan), we identified national trends:

- orientation to international educational standards for training specialists - in Kazakhstan in accordance with the principles of the Bologna Declaration in Germany and Lithuania - in accordance with the provisions of the European Union.

- the structure and content of the formation of professional competences of social pedagogues are determined by national characteristics of training specialists in the social sphere.

The research revealed the features of educational programs for training social pedagogues in Germany, Lithuania and Kazakhstan.

Professional training of social pedagogues in Germany is aimed at acquiring professional competences that will allow graduates to be successful and make responsible decisions in various areas of social and pedagogical work. Educational programs ensure the unity of theoretical and practical training of social pedagogues and combine elements of both social work and social pedagogy.

Professional programs of higher education institutions of Lithuania in the specialty "Social pedagogy" are aimed at training a specialist who can organize preventive work, work with groups of students and their families, teach communication and cooperation skills, and contribute to the personal and professional development of a social pedagogue. Special attention is paid to the training of social pedagogues to provide children with conditions for socialization, early prevention and socio-pedagogical rehabilitation.

The Educational program in the specialty "Social pedagogy and self-cognition" implemented in the educational process of higher education institutions of Kazakhstan is aimed at developing the student's personality as an individual by choosing the content, forms and methods of training that correspond to its real capabilities, needs and interests. The final result of the implementation of this model is focused on the training of professionally competent specialists in the social sphere who have a set of developed competences. The State Mandatory Standard of Education formulates the requirements for the key, subject and special competences of a bachelor's degree in "Social pedagogy and self-cognition". However, it should be noted that the competences formulated in the SMSE do not provide for the formation of professional competences for future social pedagogues to work with people with disabilities and SEN. Each discipline of the educational program "6B018-Social pedagogy and self-cognition" has opportunities to train a social pedagogue to work in an inclusive education Nevertheless, we suggest these opportunities to be specified and disclosed both in the educational program and in the State Mandatory Standard of Education of the Republic of Kazakhstan for the training of social pedagogues.

\section{Bibliography}

1. Anspoka Z., Kazaka D. (2019). Teachers during Education Reforms: Challenges and Opportunities. In V. Dislere (Ed.), The Proceedings of the International Scientific Conference Rural Environment. Education. Personality (REEP), 12. Jelgava: Latvia University of Life Sciences and Technologies, 22-27. doi: 10.22616/REEP.2019.002

2. Bachelor: Social Pedagogy. (2019). Leuphana University. Retrieved from https://www.leuphana.de/en/college/bachelor/teacher-education/social-pedagogy-ba.html 
3. Bakalavriat. Fakul'tet filosofii I politologii. Kafedra pedagogiki I obrazovatel'nogo menedzhmenta [Bachelor's programme. Faculty of Philosophy and Political Science. Department of Pedagogy and Educational management]. (2019). Retrieved from https://www.kaznu.kz/ru/8712 (in Russian)

4. Cameron C., Moss P. (Eds.). (2011). Social Pedagogy and Working with Children and Young People. Where care and education meet. London: Jessica Kingsley Publishers.

5. Delcheva T. (2019). Aspects of the practical training of social pedagogues. Pedagogika. 91(3), 352-361.

6. Dreyer L.M. (2017). Inclusive education. In L. Ramrathan, L. Grange, P. Higgs (Eds.), Education for initial teacher training. Kenwyn, South Africa:Juta \& Company Ltd

7. Durana P., Chlebikova D. (2017). The impact of globalization for need of social pedagogues in schools. In P. Hájek, O. Vít, P., Bašová, M. Krijt, H. Paszeková, O. Součková, R. Mudř́k (Eds.), The Proceedings of International Conference Innovations in Science and Education, 5. Prague: CBU, 592-587. doi: 10.12955/cbup.v5.990

8. Gasaymeh A. (2018). A study of undergraduate students' use of Information and Communication Technology (ICT) and the factors affecting their use: A developing country perspective. Eurasia Journal of Mathematics, Science and Technology Education, 14(5), 1731-1746. doi: 10.29333/ejmste/85118

9. Gosudarstvennyi obshyeobyazat'elnyi standart obrazovaniya Respubliki Kazakhstan.Bakalavriat. Special'nost' "Social'naya pedagogika i samopoznaniye" [State mandatory standard of education of the Republic of Kazakhstan. Bachelor course. Specialty "Social pedagogy and self-cognition"]. (2010). Ministry of education and science of the Republic of Kazakhstan. Astana. Retrieved from (in Russian)

10. Hämäläinen J. (2003). Developing social pedagogy as an academic discipline. In A. Gustavsson, H.E. Hermansson, J. Hämäläinen (Eds), Perspectives and theory in social pedagogy. Goteborg: Bokförlaget Daidalos A.B., 133-153

11. Hämäläinen J. (2019). Social Pedagogy as a Scientific Discipline, a Branch of Academic Studies and a Field of Professional Practice. EccoS - Revista Científica, 48, 17-34. doi: 10.5585/eccos.n48.12393

12. Kyriacou C., Ellingsen I.T., Stephens P., Sundaram V. (2009). Social pedagogy and the teacher: England and Norway compared. Pedagogy, Culture \& Society 17(1), 75-87. doi: 10.1080/14681360902742902

13. Loeb S., Dynarski S., McFarland D., Morris P., Reardon S., Reber S. (2017). Descriptive analysis in education: A guide for researchers. (NCEE 2017-4023). Washington, DC: U.S. Department of Education, Institute of Education Sciences, National Center for Education Evaluation and Regional Assistance. Retrieved from https://files.eric.ed.gov/fulltext/ED573325.pdf

14. Moss P., Petrie P. (2019). Education and social pedagogy: What relationship? London Review of Education, 17(3), 393-405. doi: 10.18546/LRE.17.3.13

15. Obrazovatel'naya programma Podgotovka specialistov po "Social'noi pedagogike i samopoznaniyu - 6B018" [Educational program "6B018-Social pedagogy and self-cognition"]. (2020). Al-Farabi Kazakh National University (in Russian). Retrieved from https://www.enu.kz/downloads/iyul-2020/6b01823-sps.doc

16. Ratheeswari K. (2018). Information Communication Technology in Education. Journal of Applied and Advanced Research, 3(S1), 45-47. doi: 10.21839/jaar.2018.v3iS1.169

17. Smekalova L., Nemejc K. (2016). Transferable Competencies of Graduates of Vocational Education: a Retrospective Survey 2007-2014. In V. Dislere (Ed.), The Proceedings of the International Scientific Conference Rural Environment. Education. Personality (REEP), 9. Jelgava: LLU, 94-103. Retrieved from https://lufb.llu.lv/conference/REEP/2016/Latvia-Univ-Agricult-REEP-2016proceed2255-808X-106-113.pdf

18. Shashkov A.V., Maznichenko M.A., Kravchenko L.V., Ivanova M.N. (2020). Students' Social-Perceptive Attitudes toward the Chosen Pedagogical Profession and the Correlation between these Attitudes and their Personal Characteristics. European Journal of Contemporary Education. 9(1), 145-159. doi: 10.13187/ejced.2020.1.145

19. Social pedagogues. (2019). Utena University of Applied Sciences. Lithuania. Retrieved from https://www.utenos-kolegija.lt/en/studies-program/social-pedagogy.

20. Spencer L.M., Spencer S.M. (1993). Competence at Work: Models for superior performance. John Wiley\& Sons.

21. The professional competences of social educators a conceptual framework. (2008). International Association of Social Educators. Retrieved from http://www.thetcj.org/wpcontent/uploads/2008/03/aieji.pdf

22. UNESCO. (1994). The Salamanca Statement and Framework for Action on Special Needs Education. Paris: UNESCO. Retrieved from https://www.european-agency.org/sites/default/files/salamanca-statement-andframework.pdf

23. Vocational Education and Training Standard for a Social Pedagogue. (2008). Ministry of Education and Science. Ministry of Social security and Labour. Retrieved from https://www.kpmpc.lt/Standartai/EN/Socialinis_pedagogas.EN.5.pdf 